\title{
Genetic parameters and multi-trait selection of white oats for forage
}

\author{
T.C. da Rosa ${ }^{1}$, I.R. Carvalho ${ }^{2}$, J.A.G. da Silva ${ }^{2}$, V.J. Szareski ${ }^{1}$, \\ T.A. Segatto ${ }^{2}$, E.D. Port ${ }^{2}$, M.V. Loro ${ }^{2}$, H.C.F. Almeida ${ }^{3}$, \\ A.C. de Oliveira ${ }^{1}$, L.C. da Maia ${ }^{1}$ and V.Q. de Souza ${ }^{4}$ \\ ${ }^{1}$ Universidade Federal de Pelotas, Capão do Leão, RS, Brasil \\ ${ }^{2}$ Universidade Regional do Noroeste do Estado do Rio Grande do Sul, Ijuí, \\ RS, Brasil \\ ${ }^{3}$ Universidade Federal de Viçosa, Viçosa, MG, Brasil \\ ${ }^{4}$ Universidade Federal de Pampa, São Gabriel, RS, Brasil \\ Corresponding author: I.R. Carvalho \\ E-mail: carvalho.irc@gmail.com
}

Genet. Mol. Res. 20 (2): gmr18451

Received July 25, 2019

Accepted September 28, 2020

Published July 29, 2021

DOI http://dx.doi.org/10.4238/gmr18451

\begin{abstract}
Avena sativa is the sixth most produced cereal in the world. It is widely used for human consumption. Due to the bromatological quality of its forage, it is used for direct grazing, hay and silage. Due to the large number of interesting characteristics of forage white oats, the selection of unique characteristics becomes difficult and expensive for breeders. In this sense, the use of analysis with multiple characteristics can facilitate the process. Therefore, the objective of this work was to estimate genetic parameters of morphological characteristics, productivity, and quality of forages, as well as to define multiple characteristics that assist in the selection of promising white oat genotypes with forage profile through factor analysis. Field trials were carried out during the agricultural year of 2013 in the municipality of Capão do Leão, RS. The experimental design was in randomized blocks, with treatments arranged in four replications. The treatments corresponded to the genotypes CHIARASUL (G1), FAEM006 (G2), BARBARASUL (G3), BRISASUL, (G4) CGF03006 (G5), CGF07023-1 (G6), CGF07-74 027-1 (G7), CGF07033 (G8), CGF07033-1 (G9), CGF07041 (G10), CGF0705-7 (G11), CGF07060-2 (G12) and CGF07060-3 (G13). The
\end{abstract}


characteristics analyzed were: plant height, leaf area, weight of fresh plants, weight of dry plants, number of tillers and levels of nitrogen, crude protein, phosphorus, potassium, calcium, magnesium, copper, zinc, manganese and iron. The data were submitted to the normality test and to various components of variance. Statistical analyses were performed using Selegen ${ }^{\circledR}$, SAS ${ }^{\circledR}$ and Genes ${ }^{\circledR}$ software. The white oat genotypes expressed high genetic variability and possibility of selection for leaf area, fresh forage mass, dry forage mass, number of tillers and calcium content. Simultaneously the magnesium content with multiple traits + zinc content, dry matter + fresh mass, nitrogen content + calcium content, crude protein + potassium content and number of tillers, showing potential to select genotypes of interest for genetic improvement.

Key words: Avena sativa; Generation mean analysis; Effects of genes; Factor analysis

\section{INTRODUCTION}

White oats (Avena sativa L.) is the sixth most produced cereal in the world (Suttie and Reynolds, 2004), can be used for human consumption (Nava et al., 2010), in management techniques for soil cover, crop rotation and nutrient cycling (Kim et al., 2014), direct pasture, hay and silage (Huuskonen, 2009). Thus, white oats have great potential for feeding meat and dairy herds, to be used in crop rotation, and crop-livestock integration systems, aiming to maximize the sustainability of agricultural systems (David et al., 2010).

Genetic breeding prioritizes the development of white oat genotypes with forage profile that present high forage yield and quality, digestibility and acceptability by the animals (Suttie and Reynolds, 2004). However, traits of importance for forage production are generally controlled by numerous genes with low heritability and strong influence of the growing environment. Considering it, the knowledge about the genetic nature of traits of interest is essential to define which are determinant for forage yield and quality, as well as to verify the influence of growing environments. This information guides breeders to select the best genotypes through one or more traits of interest (Roy et al., 2013). To achieve genetic gains through selection, breeders must understand the nature of the objective trait and quantify the fractions of total variation by estimating variance components and genetic parameters. These estimations will support the selection of genotypes based on predicted genetic value of the trait of interest (Lourenço et al., 2017). Therefore, mixed models enable to maximize genotypes selection through accurate and efficient estimates of variance components and genetic parameters (Resende, 2016). The restricted maximum likelihood (REML) allows to estimate genetic parameters to be used in the prediction of genetic value through the best linear unbiased predictor (BLUP) approach (Ticona-Benavent and Silva Filho, 2015). The combined use of these methodologies allows to rank and select promising genotypes for traits of interest (Borges et al., 2010).

Due to the large number of traits of interest for forage white oats, selecting single traits becomes difficult and expensive for breeders (Rocha et al., 2017). In order to identify which traits should compose a multi-trait, the analysis of factors, widely diffused for the 
stratification of environments, adaptability and stability (Nuvunga et al., 2015; Carvalho et al., 2016), may be pioneeringly used to identify multi-traits aimed to select white oat genotypes with forage profile. It would allow to simultaneously select morphological aspects, components of forage yield and bromatological quality. Therefore, the objective of this work was to estimate genetic parameters of morphological traits, forage yield and quality, as well as to define multi-traits that aid the selection of promising white oat genotypes with forage profile through factor analysis.

\section{MATERIAL AND METHODS}

Field trials were conducted during 2013 agricultural year in the experimental area of the Plant Genomics and Breeding Center of the Federal University of Pelotas, located in the municipality of Capão do Leão - RS. The geographic coordinates correspond to latitude $31^{\circ} 47^{\prime} 58^{\prime \prime} \mathrm{S}$ and longitude $52^{\circ} 31^{\prime} 02^{\prime \prime} \mathrm{W}$, with altitude of $13.24 \mathrm{~m}$. According to Köppen, the climate is characterized as Cfa subtropical, and the soil as dystrophic yellow red Argisoil.

The experimental design was randomized blocks, with treatments arranged in four replications. The treatments corresponded to the genotypes CHIARASUL $\left(\mathrm{G}_{1}\right)$, FAEM006 $\left(\mathrm{G}_{2}\right)$, BARBARASUL $\left(\mathrm{G}_{3}\right)$, BRISASUL, $\left(\mathrm{G}_{4}\right)$ CGF03006 $\left(\mathrm{G}_{5}\right)$, CGF07023-1 $\left(\mathrm{G}_{6}\right)$, CGF07027-1 $\left(\mathrm{G}_{7}\right)$, CGF07033 $\left(\mathrm{G}_{8}\right)$, CGF07033-1 $\left(\mathrm{G}_{9}\right)$, CGF07041 $\left(\mathrm{G}_{10}\right)$, CGF0705-7 $\left(\mathrm{G}_{11}\right)$, CGF07060-2 $\left(\mathrm{G}_{12}\right)$ and CGF07060-3 $\left(\mathrm{G}_{13}\right)$.

The experimental area was managed under no-tillage system, with base fertilization of $400 \mathrm{~kg} \mathrm{ha}^{-1}$ of NPK in the formulation $05-20-20$, and $150 \mathrm{~kg} \mathrm{ha}^{-1}$ of nitrogen at full tillering stage (stage 21) of the scale of Zadoks et al. (1974). The population density used for all genotypes was 300 plants $\mathrm{m}^{-2}$. The experimental units were composed by five rows, spaced 0.17 meters (m), with five meters (m) length, totaling $4.25 \mathrm{~m}^{2}$ per parcel. The management of weeds and pest insects were carried out according to the crop's demand to minimize biotic effects. The traits were measured at the booting stage (stage 41) (Zadoks et

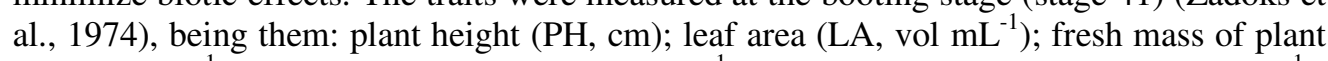
(FM, g plant $\left.{ }^{-1}\right)$; dry mass of plant (DM, g plant $\left.{ }^{-1}\right)$; NT: number of tillers (NT, units $\mathrm{m}^{-1}$ ); nitrogen content $\left(\mathrm{N}, \mathrm{g} \mathrm{kg}^{-1}\right)$; crude protein $(\mathrm{CP}, \%)$; phosphorous content $\left(\mathrm{P}, \mathrm{g} \mathrm{kg}^{-1}\right)$; potassium content $\left(\mathrm{K}, \mathrm{g} \mathrm{kg}^{-1}\right)$; calcium content $\left(\mathrm{Ca}, \mathrm{g} \mathrm{kg}^{-1}\right)$; magnesium content $\left(\mathrm{Mg}, \mathrm{g} \mathrm{kg}^{-}\right.$ $\left.{ }^{1}\right)$; cupper content $\left(\mathrm{Cu}, \mathrm{mg} \mathrm{kg}^{-1}\right)$; zinc content $\left(\mathrm{Zn}, \mathrm{mg} \mathrm{kg}^{-1}\right)$; manganese content $(\mathrm{Mn}, \mathrm{mg}$ $\left.\mathrm{kg}^{-1}\right)$ and iron content $\left(\mathrm{Fe}, \mathrm{mg} \mathrm{kg}^{-1}\right)$.

The data were submitted to normality test by Shapiro Wilk (1965), and Deviance analysis at $5 \%$ of probability by the chi-square test $\left(\mathrm{X}^{2}\right)$. The components of variance and genetic parameters for white oat genotypes were estimated using the statistical model $y=X r$ $+Z g+e$, where: $y$ is the data vector, $r$ are the effects of replicates (fixed) added to the general average; $g$ are the genetic effects (random); $e$ are the effects of residue (random). The variance components were: genetic variance $\left(\hat{\sigma}^{2} g\right)$, residual variance $\left(\hat{\sigma}^{2} e\right)$, phenotypic variance $\left(\hat{\sigma}^{2} p\right)$, broad sense heritability $\left(H^{2} g\right)$, broad sense heritability of genotypes' average $\left(H^{2} m l\right)$, accuracy of selection (Aclinh), coefficient of genetic variation (CVgi), coefficient of residual variation $(\mathrm{CVe})$ and overall mean of the experiment $(O M)$. After, the factor analysis was applied (Murakami and Cruz,2004), following the statistical model $X j=I j 1 F 1+I j 2 F 2$ $+\ldots+\operatorname{IjmFm}+\varepsilon j$, where $\mathrm{Xj}$ corresponds to the trait of interest $(\mathrm{j}=1,2,(\mathrm{v})$, Ij represents the factorial load of the $\mathrm{j}^{\text {th }}$ variable associated to the $\mathrm{k}^{\text {th }}$ factor, where $\mathrm{k}=1,2, \ldots \mathrm{m}$ (number of common factors); Fk represents the $\mathrm{j}^{\text {th }}$ factor, and $\varepsilon \mathrm{j}$ refers to the error associated to a 
specific factor (Murakami and Cruz, 2004). Statistical analyzes were performed through the software Selegen ${ }^{\circledR}$ (Resende, 2016), SAS ${ }^{\circledR}$ (SAS Institute, 2018) and Genes ${ }^{\circledR}$ (Cruz, 2016).

\section{RESULTS AND DISCUSSION}

\section{Components of variance and genetic parameters}

Deviance analysis by the Likelihood Ratio Test (LRT) revealed significance at 5\% of probability through the chi-square $\left(\mathrm{x}^{2}\right)$ test for the traits plant height $(\mathrm{PH})$, leaf area (LA), fresh mass of forage $(\mathrm{FM})$, nitrogen content $(\mathrm{N})$, crude protein $(\mathrm{CP})$, phosphorus content $(\mathrm{P})$, potassium content $(\mathrm{K})$, calcium content $(\mathrm{Ca})$, dry mass of forage $(\mathrm{DM})$, number of tillers $(\mathrm{Ca})$, magnesium content $(\mathrm{Mg})$, zinc content $(\mathrm{Zn})$ and manganese content $(\mathrm{Mn})$. On the other hand, the traits copper content $(\mathrm{Cu})$ and iron content $(\mathrm{Fe})$ did not reveal significance (Table 1).

The estimates of genetic variance obtained were high for most of the measured and significant traits. In general, controlling phenotypic variation through the adjustment of experimental techniques allows to increase broad sense heritability and thereby to understand the total genetic variation present in a specific breeding situation. It will increase the probability of identifying genotypes that attend the agronomic ideotype. Plant height $(\mathrm{PH})$ evidenced that $77.5 \%$ of the phenotypic manifestation was due to total genetic effects $\left(\hat{\sigma}_{\mathrm{g}}{ }_{\mathrm{g}}\right)$, which comes from a high broad sense heritability $\left(\mathrm{H}^{2} \mathrm{~g}: 0,77\right)$ (Table 1). Researchers defined estimates of $\mathrm{H}^{2} \mathrm{~g}$ : 0.67 for PH, similar with this study (Roy et al., 2013). The genetic breeding of white oats prioritizes genotypes with determined stature which would allow to minimize unnecessary assimilate expenses in the development of expendable structures (drains), to reduce lodging, and to direct assimilates for the maximum accumulation of biomass in leaves and stems. Intermediate magnitudes of $\mathrm{PH}$, ranging between 48 and 108.5 $\mathrm{cm}$, are prioritized for forage white oats (Gill et al., 2013; Irfan et al., 2016), which covers the general mean of the studied genotypes (OM: $66.51 \mathrm{~cm})$.

Leaf area (LA) evidenced that $89.9 \%$ of the phenotypic variance was due to genetic causes, resulting in high broad sense heritability (Table 1). Although this trait is strongly dependent and influenced by intrinsic edaphoclimatic conditions of each growing environment. The high magnitude of genetic variance determines the possibility of obtaining gains with selection and thus incrementing the objective trait.

Fresh mass (FM) and dry mass of forage (DM) represent the forage yield per unit of area, considering that the evaluation of green mass is not accurate and might be influenced by the fraction of liquids present on plant tissues at the moment of evaluation (Table 1). Therefore, estimates and inferences are based on dry mass in order to obtain greater accuracy of selection (Joubert and Myburgh, 2014). The phenotypic variations observed for FM and DM were determined in 92.59 and $91.87 \%$, respectively, by total genetic effects, which is reaffirmed by their respective estimates of broad sense heritability (0.92 and 0.91$)$. These estimates are higher than those observed by Dubey et al. $(2014)\left(\mathrm{H}^{2} \mathrm{~g}=0.68\right)$ and Roy et al., (2013) $\left(\mathrm{H}^{2} \mathrm{~g}=0.39\right)$ for dry mass of forage. The number of tillers (NT) presented high genetic variance $(94.10 \%)$, close to the value obtained by Bibi et al. (2012), who verified broad sense heritability of $0.99 \%$. The increase on the number of tillers is associated to higher forage and grain yield (Deiss et al., 2014). 
The evaluation of nitrogen content $(\mathrm{N})$ indirectly allows to estimate the fraction of crude protein $(\mathrm{CP})$ in the forage. $\mathrm{CP}$ gathers the true protein fraction and the non-protein nitrogen fraction, as both of which play determinant physiological role on animal organism (Kumar et al., 2017). These traits present $50 \%$ and $73 \%$ of total genetic effects determining their phenotypic variation, respectively. Roy et al. (2013) found $76.74 \%$ of broad sense heritability evaluating crude protein content in white oats forage, therefore, this high magnitude indicates the possibility of achieving genetically superior individuals through phenotypic selection.

The physiological and nutritional performance of forage plants depends on the availability of macro and micronutrients in their forage. The proportion of these elements found in plants varies according to intrinsic characteristics of genotype, phenological stage, growing environment and genotype by environment interaction, therefore, their evaluation is essential (Liu and Mahmood, 2015). The macro minerals phosphorus (P), potassium (K), calcium $(\mathrm{Ca})$ and magnesium $(\mathrm{Mg})$ play important structural and physiological role in the animal organism (Soetan et al., 2010). Thereby, forages with higher accumulation of these nutrients tend to meet animal's demands. The phenotypic variations observed for phosphorus $(\mathrm{P})$ and magnesium $(\mathrm{Mg})$ were determined by 67.5 and $68.0 \%$ of total genetic effects. In contrast, potassium $(\mathrm{K})$ and calcium $(\mathrm{Ca})$ revealed 0.74 and $0.81 \%$ of genetic contributions on their respective phenotypic variations. These macro minerals presented high estimates of broad sense heritability. Evaluating different varieties of forage white oats, Gill et al. (2013) verified overall means of macro minerals $\left(\mathrm{P}=0,4 \mathrm{~g} \mathrm{~kg}^{-1} ; \mathrm{K}=16.2 \mathrm{~g}\right.$ $\mathrm{kg}^{-1} ; \mathrm{Ca} 2,8 \mathrm{~g} \mathrm{~kg}^{-1} ; \mathrm{Mg}=12,0 \mathrm{~g} \mathrm{~kg}^{-1}$ ) inferior to those verified by this study, except for $\mathrm{Mg}$ $\left(\mathrm{P}=5.24 \mathrm{~g} \mathrm{~kg}^{-1} ; \mathrm{K}=41.95 \mathrm{~g} \mathrm{~kg}^{-1} ; \mathrm{Ca} 4.52 \mathrm{~g} \mathrm{~kg}^{-1} ; \mathrm{Mg}=2.87 \mathrm{~g} \mathrm{~kg}^{-1}\right.$ ) (Table 1).

The microminerals or trace elements analyzed present a diverse range of functions in both animal and plant organisms, however the proportion of microminerals required is lower than macrominerals (Yatoo et al., 2013). Among the microminerals analyzed, the highest percentage of genotypic variance was evidenced by manganese $(\mathrm{Mn})$ content $(0.73 \%)$, which presented high estimate of broad sense heritability. The content of zinc ( $\mathrm{Zn})$ verified in the forage presents $57 \%$ of genetic variance, and intermediate estimate of broad sense heritability Iron $(\mathrm{Fe})$ and copper $(\mathrm{Cu})$ presented the lowest percentages of genotypic variance $(0.29 \%$ and $0.00 \%$, respectively), evidencing low genetic control on these trait's manifestation and high influence of the environment, which hinders the achievement of superior individuals. The overall means observed for these microminerals $\left(\mathrm{Cu}=1.5 \mathrm{mg} \mathrm{kg}^{-1}\right.$; $\mathrm{Zn}=29.81 \mathrm{mg} \mathrm{kg}^{-1} ; \mathrm{Mn}=99.72 \mathrm{mg} \mathrm{kg}^{-1} ; \mathrm{Fe}=124.68 \mathrm{mg} \mathrm{kg}^{-1}$ ) (Table 1), differed from the values observed by Gill et al. (2013) $\left(\mathrm{Cu}=5.35 \mathrm{mg} \mathrm{kg}^{-1} ; \mathrm{Zn}=19.5 \mathrm{mg} \mathrm{kg}^{-1} ; \mathrm{Mn}=66.9 \mathrm{mg} \mathrm{kg}^{-}\right.$ ${ }^{1} ; \mathrm{Fe}=288.8 \mathrm{mg} \mathrm{kg}^{-1}$ ).

The reliability of results and precision of procedures used to estimate the genetic parameters may be verified through the selective accuracy (Aclinh). This parameter is associated with the precision of selection and refers to the ratio between predicted genetic value and the true genetic magnitude (Pimentel et al., 2014). Aclinh magnitudes vary from 0 to 1 and are classified as very high (Aclinh $\geq 0.90)$, high $(0.70 \leq$ Aclinh $<0.90)$, moderate $(0.50 \leq$ Aclinh $<0,70)$ and low (Aclinh <0.50) (Resende and Duarte, 2007). Aclinh estimates above 0.70 are sufficient to accurately infer the genetic value of genotypes (Resende, 2002). Considering the verified aclinh values, only $\mathrm{Cu}$ content did not meet this requirement (Aclin: 0.10). 
The coefficient of genetic variation $\left(C V_{g i}\right)$ is a parameter commonly used to compare the genetic variability present in a trait of study (Resende, 2002). The $C V_{g i}$ varied from low to high in the set of evaluated traits, being the lowest value presented by $\mathrm{Cu}$ $(1.31 \%)$, which demonstrates its low genetic variability in relation to the average of genotypes studied. In contrast, high values of $C V_{g i}$ were observed for the traits NT $\left(C V_{g i}: 25.24\right)$, FM $\left(C V_{g i}: 24.25\right)$, DM $\left(C V_{g i}: 23.76\right)$ e LA $\left(C V_{g i}: 22.01\right)$, which demonstrates their high genetic variability and enables the breeder to select superior individuals. The coefficients of residual variation $\left(\mathrm{CV}_{e}\right)$ were classified from low to medium for majority of the evaluated traits, with only $\mathrm{Fe}$ and $\mathrm{Cu}$ presenting intermediate to high $C V_{e}$ (17.86 and 21.42 , respectively) (Table 1). It demonstrates accuracy and expresses the reliability of the data. A relation between $C V_{g i}$ and $C V_{e}$ of 1 or more reflects favorable situation to achieve gains with selection (Vencovsky, 1978). This situation was verified for most of the studied traits, except $\mathrm{Cu}$ and $\mathrm{Fe}$, which indicates the possibility of achieving gains with selection (Table 1).

Table 1. Estimates of variance components and genetic parameters for plant height (PH), leaf area (LA), dry mass of forage (DM), fresh mass of forage (FM), number of tillers (NT), nitrogen content $(\mathrm{N})$, crude protein $(\mathrm{CP})$, phosphorus content $(\mathrm{P})$, potassium content $(\mathrm{K})$, calcium content $(\mathrm{Ca})$, magnesium content $(\mathrm{Mg})$, copper content $(\mathrm{Cu})$, zinc content $(\mathrm{Zn})$, manganese content $(\mathrm{Mn})$ and iron content $(\mathrm{Fe})$ measured in white oat genotypes.

\begin{tabular}{|c|c|c|c|c|c|c|c|c|}
\hline $\begin{array}{l}\text { Components } \\
\text { of variance }^{+}\end{array}$ & $\mathrm{PH}^{++}$ & LA & DM & FM & NT & $\mathrm{N}$ & $\mathrm{CP}$ & $\mathrm{P}$ \\
\hline Deviance $^{++}$ & 109.50 & 245.88 & 111.15 & 219.08 & 131.55 & 83.84 & 7.37 & 16.01 \\
\hline LRT & $12.71 * *$ & $29.98 * *$ & $29.05 * *$ & $31.34 * *$ & $36.42 * *$ & $8.36 * *$ & $21.34 * *$ & $16.85 * *$ \\
\hline$\hat{\sigma}_{g}^{2}$ & 22.04 & 6066.79 & 47.13 & 2716.93 & 122.06 & 1.92 & 0.48 & 0.50 \\
\hline$\hat{\sigma}_{\mathrm{e}}^{2}$ & 6.39 & 674.51 & 4.16 & 217.16 & 7.64 & 1.91 & 0.17 & 0.23 \\
\hline$\hat{\sigma}_{\mathrm{p}}^{2}$ & 28.43 & 6741.30 & 51.30 & 2934.09 & 129.70 & 3.84 & 0.65 & 0.74 \\
\hline$\widehat{\mathrm{H}}_{\mathrm{g}}^{2}$ & 0.77 & 0.89 & 0.91 & 0.92 & 0.94 & 0.50 & 0.73 & 0.67 \\
\hline $\mathrm{H}_{\mathrm{ml}}^{2}$ & 0.91 & 0.96 & 0.97 & 0.97 & 0.97 & 0.75 & 0.89 & 0.86 \\
\hline $\mathrm{AC}_{\text {linh }}$ & 0.95 & 0.98 & 0.98 & 0.98 & 0.98 & 0.86 & 0.94 & 0.92 \\
\hline CVgi $\%$ & 7.05 & 22.01 & 23.76 & 24.25 & 25.24 & 4.40 & 14.16 & 13.49 \\
\hline $\mathrm{CVe} \%$ & 3.80 & 7.33 & 7.06 & 6.85 & 6.31 & 4.39 & 8.42 & 9.32 \\
\hline Overall mean & $66.51 \mathrm{~cm}$ & $353.85 \mathrm{vol} \mathrm{mL}^{-1}$ & $\begin{array}{l}28.88 \mathrm{~g} \\
\text { plant }^{-1}\end{array}$ & $\begin{array}{l}214.87 \mathrm{~g} \\
\text { plant }^{-1}\end{array}$ & $\begin{array}{l}43.75 \text { units } \\
\mathrm{m}^{-1}\end{array}$ & $\begin{array}{l}31.54 \mathrm{~g} \\
\mathrm{~kg}^{-1}\end{array}$ & $4.92 \%$ & $5.24 \mathrm{~g} \mathrm{~kg}^{-1}$ \\
\hline $\begin{array}{l}\text { Components of } \\
\text { variance }\end{array}$ & K & $\mathrm{Ca}$ & $\mathrm{Mg}$ & $\mathrm{Cu}$ & \multicolumn{2}{|c|}{$\mathrm{Zn}$} & $\mathrm{Mn}$ & $\mathrm{Fe}$ \\
\hline Deviance & 78.2 & 24.44 & 47.7 & 37.91 & \multirow{2}{*}{\multicolumn{2}{|c|}{$\begin{array}{l}118.89 \\
10.85^{* *}\end{array}$}} & 241.11 & 269.46 \\
\hline LRT & $21.80 * *$ & $20.29 * *$ & $20.83 * *$ & $0.00^{\mathrm{ns}}$ & & & $18.08^{* * *}$ & $2.83^{\text {ns }}$ \\
\hline$\hat{\sigma}_{\mathrm{g}}$ & 3.80 & 0.27 & 0.09 & 0,00 & \multicolumn{2}{|c|}{6.84} & 377.65 & 208.79 \\
\hline$\hat{\sigma}_{\mathrm{e}}$ & 1.26 & 0.06 & 0.04 & 0.10 & \multicolumn{2}{|c|}{5.13} & 136.57 & 496.29 \\
\hline $\begin{array}{l}\hat{\sigma}_{\mathrm{p}} \\
\hat{\sigma}_{\mathrm{p}}\end{array}$ & 5.06 & 0.33 & 0.13 & 0.10 & \multicolumn{2}{|c|}{11.98} & 514.23 & 705.09 \\
\hline $\mathrm{H}_{\mathrm{g}}^{2}$ & 0.74 & 0.81 & 0.68 & 0,00 & \multicolumn{2}{|c|}{0.57} & 0.73 & 0.29 \\
\hline $\mathrm{H}_{\mathrm{ml}}^{\mathrm{g}}$ & 0.89 & 0.92 & 0.86 & 0.01 & \multirow{2}{*}{\multicolumn{2}{|c|}{$\begin{array}{l}0.79 \\
0.89\end{array}$}} & 0.89 & 0.55 \\
\hline $\mathrm{Ac}_{\text {linh }}$ & 0.94 & 0.96 & 0.93 & 0.10 & \multirow{2}{*}{\multicolumn{2}{|c|}{$\begin{array}{l}0.89 \\
877\end{array}$}} & 0.94 & 0.74 \\
\hline CVgi \% & 4.64 & 11.49 & 10.59 & 1.31 & & & 19.48 & 11.58 \\
\hline $\mathrm{CVe} \%$ & 2.68 & 5.52 & 7.21 & 21.42 & \multicolumn{2}{|c|}{7.60} & 11.71 & 17.86 \\
\hline Overall mean & $41.95 \mathrm{~g} \mathrm{~kg}^{-}$ & $4.52 \mathrm{~g} \mathrm{~kg}^{-1}$ & $2.87 \mathrm{~g} \mathrm{~kg}^{-1}$ & $1.50 \mathrm{mg} \mathrm{kg}^{-1}$ & \multicolumn{2}{|c|}{$29.81 \mathrm{mg} \mathrm{kg}^{-1}$} & $99.72 \mathrm{mg} \mathrm{kg}^{-1}$ & $124.68 \mathrm{mg} \mathrm{kg}^{-1}$ \\
\hline
\end{tabular}

${ }^{+} \hat{\sigma}_{\mathrm{g}}$ : Genotypic variance; $\hat{\sigma}_{\mathrm{e}}$ : residual variance (environmental); $\hat{\sigma}_{\mathrm{p}}$ : phenotypic variance; $\hat{\mathrm{H}}_{\mathrm{g}}^{2}:$ B Broad sense heritability of the genotype; $\widehat{\mathrm{H}}_{\mathrm{ml}}^{2}$ : heritability of the lineage average; Aclinh: Selective accuracy; $\mathrm{CVgi} \%$ : Coefficient of genetic variation; Ve\%: Coefficient of residual variation; overall mean; ${ }^{+}$Deviance at $5 \%$ of probability by the chi-square test; LRT: Likelihood ratio test.

\section{Best Linear Unbiased Predictor (BLUP)}

The estimates of variance components and genetic parameters allowed to apply the BLUP methodology, and then estimate the percentage of gain with selection, the new mean and the predicted genetic value of each genotype (Resende, 2016). For the trait plant height 
(PH) (Table 2), it is possible to obtain increment of $18 \%$ by selecting the genotype CGF03006. However, studies have defined that plant height is the main contributor to lodging, and consequently, yield reduction (Berry and Berry, 2015). Thus, genetic breeding of white oats for forage purposes preconizes the reduction of stem length and increment of leaves per plant (Tumino et al., 2017). In this context, the genotypes CGF07-027-1, BARBARASUL, CHIARASUL and CGF07023-1 presented the lowest predicted genetic values, and their selection does not result in plant height increment.

The selection of white oat genotypes with short stature due to a reduced length of internodes contributes to increase the leaf/stem ratio in the forage. The increment of leaf content in relation to stalk content is of great interest for forage breeders because of the higher nutritional quality and digestibility of foliar tissues (Tremblay et al., 2001). Also, the increase in leaf area results in larger photosynthetically active area, which elevates the plant's capacity to produce photoassimilates and consequently, dry matter of high quality per unit of area (Saleem et al., 2015). The highest gains with selection for leaf area (Table 2) were evidenced through the genotypes BRISASUL (14.30\%), CGF07-027-1 (13.76\%) and CGF0705-7 (11.20\%). The selection of superior genotypes for this trait is fundamental to elevate leaf/stem ratio and forage yield. This situation is expressed by the genotypes BRISASUL and CGF07-027-1, which presented the highest predicted means (437.46 vol mL e 434,31 vol mL $\mathrm{mL}^{-1}$, respectively). However, these same genotypes did not present similar estimates for fresh mass (FM) and dry mass (DM). These results limit their use for forage production, since the priority is to select genotypes with the greatest capacity for green and dry mass production. Considering it, the genotype CGF07033-1 evidenced the greatest predicted mean for FM (273.55 g plant $\left.^{-1}\right)$ and DM (41.19 $\left.\mathrm{g} \mathrm{plant}^{-1}\right)$, demonstrating potential for high forage yield.

The number of tillers (NT) (Table 2) presented dynamics similar to leaf area (LA). Thus, the highest predicted means were verified through the genotypes CGF07027-1 and BRISASUL. However, the high number of tillers expected for their new means is followed by low estimate of green and dry mass production. This fact can be explained by the short stature of these genotypes, which result of a shorter stem length. The proportion of stem contributes largely to the mass produced per area, so a higher leaf/stem ratio may decrease the yield of fresh and dry mass. Therefore, the challenge of breeding programs of white oats with forage profile, from the morphological point of view, is to develop genotypes that present plant height, tillering and leaf area in balanced and efficient magnitudes, contributing to a higher bromatological quality, digestibility and forage yields. The white oat genotype that most approached this condition was CGF0705-7, which presented low predicted mean for $\mathrm{PH}(68.40 \mathrm{~cm})$, and high estimates for NT (51.31 units $\left.\mathrm{m}^{-1}\right)$, LA (419.31 vol mL ${ }^{-1)}$, FM (259.05 $\left.\mathrm{g} \mathrm{plant}^{-1}\right)$ and DM (38.14 g plant $\left.{ }^{-1}\right)$.

Regarding crude protein content (CP), the genotypes with the highest gains (Table 3) were BARBARASUL (17.88\%), BRISASUL (14.92\%) and CGF07023-1 $(13.80 \%)$. However, these genotypes were not ranked in the first positions for most of the macro and micronutrients measured. It results in a great difficulty to gather, in a same genotype, high protein contents and accumulation of essential nutrients. The genotype CGF0705-7 presented superiority of predicted genetic value for magnesium 
$(\mathrm{Mg})$, nitrogen $(\mathrm{N})$ and calcium $(\mathrm{Ca})$ content, thus, the selection of this genotype can simultaneously potentiate the accumulation of these nutrients in the forage. The genotype CGF07-027-1 showed superiority for accumulation of phosphorus (P) and potassium (K). The genotype FAEM006 presented superior accumulation of manganese (Mn), while the genotype CGF30006 for zinc content (Zn) (Table 3).

The results obtained through the BLUP revealed certain difficulty in selecting genotypes that simultaneously present suitable magnitudes of desirable morphological traits, high forage yield and bromatological quality. Therefore, it becomes necessary to apply a multivariate strategy to define which characters may be selected together, and also, to define which genotypes are intrinsic to these multi-traits.

Table 2. Ranking of white oats genotypes through best linear unbiased predictor (BLUP), gain with selection $(\%)$ and new predicted means for the traits plant height $(\mathrm{PH})$; leaf area $(\mathrm{LA})$; number of tillers (NT); fresh mass (FM); dry mass (DM) and crude protein (CP).

\begin{tabular}{|c|c|c|c|c|c|c|c|c|}
\hline \multicolumn{3}{|l|}{$\mathrm{PH}$} & \multicolumn{3}{|l|}{ LA } & \multicolumn{3}{|l|}{ NT } \\
\hline Lineage & $\begin{array}{l}\text { Gain } \\
(\%)\end{array}$ & New mean $(\mathrm{cm})$ & Lineage & $\begin{array}{l}\text { Gain } \\
(\%)\end{array}$ & $\begin{array}{l}\text { New mean (vol } \\
\left.\mathrm{mL}^{-1}\right)\end{array}$ & Lineage & $\begin{array}{l}\text { Gain } \\
(\%)\end{array}$ & $\begin{array}{l}\text { New mean (units } \\
\mathrm{m}^{-1} \text { ) }\end{array}$ \\
\hline CGF03006 & 18.64 & 75.12 & BRISA SUL & 14.30 & 437.46 & $\begin{array}{l}\text { CGF07-027- } \\
1\end{array}$ & 13.08 & 54.93 \\
\hline CGF07041 & 14.78 & 73.34 & $\begin{array}{l}\text { CGF07-027- } \\
1\end{array}$ & 13.76 & 434.31 & BRISA SUL & 11.90 & 53.93 \\
\hline CGF07033-1 & 13.12 & 72.58 & CGF0705-7 & 11.20 & 419.31 & CGF07023-1 & 11.35 & 53.45 \\
\hline CGF07060-3 & 12.22 & 72.16 & FAEM 006 & 9.75 & 410.86 & CGF07033-1 & 10.51 & 52.73 \\
\hline CGF07033 & 10.26 & 71.25 & CGF07060-3 & 8.80 & 405.29 & CGF07041 & 9.62 & 51.98 \\
\hline FAEM 006 & 8.71 & 70.54 & CGF03006 & 8.14 & 401.44 & CGF0705-7 & 8.84 & 51.31 \\
\hline CGF07060-2 & 7.11 & 69.80 & CGF07033-1 & 7.52 & 397.79 & CGF07033 & 8.18 & 50.74 \\
\hline BRISA SUL & 5.45 & 69.03 & CGF07033 & 6.96 & 394.56 & CGF07060-3 & 7.25 & 49.95 \\
\hline CGF0705-7 & 4.08 & 68.40 & CGF07041 & 6.44 & 391.52 & FAEM 006 & 6.44 & 49.26 \\
\hline $\begin{array}{l}\text { CGF07-027- } \\
1\end{array}$ & 2.87 & 67.84 & CGF07060-2 & 5.61 & 386.65 & CGF07060-2 & 5.64 & 48.58 \\
\hline $\begin{array}{l}\text { BARBARA } \\
\text { SUL }\end{array}$ & 1.84 & 67.37 & CGF07023-1 & 4.91 & 382.58 & CGF03006 & 4.79 & 47.85 \\
\hline $\begin{array}{l}\text { CHIARA } \\
\text { SUL }\end{array}$ & 0.93 & 66.94 & $\begin{array}{l}\text { CHIARA } \\
\text { SUL }\end{array}$ & 2.60 & 369.08 & $\begin{array}{l}\text { BARBARA } \\
\text { SUL }\end{array}$ & 2.40 & 45.80 \\
\hline CGF07023-1 & 0 & 66.51 & $\begin{array}{l}\text { BARBARA } \\
\text { SUL }\end{array}$ & 0.00 & 353.86 & $\begin{array}{l}\text { CHIARA } \\
\text { SUL }\end{array}$ & 0.00 & 43.76 \\
\hline TOTAL & 100.00 & & & 100.00 & & & 100.00 & \\
\hline FM & & & DM & & & $\mathrm{CP}$ & & \\
\hline Lineage & $\begin{array}{l}\text { Gain } \\
(\%)\end{array}$ & $\begin{array}{l}\text { New mean (g } \\
\text { plant }^{-1} \text { ) }\end{array}$ & Lineage & $\begin{array}{l}\text { Gain } \\
(\%)\end{array}$ & $\begin{array}{l}\text { New mean (g } \\
\text { plant }^{-1} \text { ) }\end{array}$ & Lineage & $\begin{array}{l}\text { Gain } \\
(\%)\end{array}$ & New mean $(\%)$ \\
\hline CGF07033-1 & 14.98 & 273.55 & CGF07033-1 & 20.46 & 41.19 & $\begin{array}{l}\text { BARBARA } \\
\text { SUL }\end{array}$ & 17.88 & 6.16 \\
\hline CGF03006 & 13.25 & 266.79 & CGF0705-7 & 15.39 & 38.14 & BRISA SUL & 14.92 & 5.96 \\
\hline CGF0705-7 & 11.28 & 259.05 & CGF07041 & 11.51 & 35.81 & CGF07023-1 & 13.80 & 5.88 \\
\hline CGF07023-1 & 9.95 & 253.87 & CGF03006 & 9.44 & 34.57 & $\begin{array}{l}\text { CHIARA } \\
\text { SUL }\end{array}$ & 11.50 & 5.72 \\
\hline CGF07060-3 & 8.88 & 249.66 & CGF07060-2 & 8.20 & 33.81 & CGF0705-7 & 9.83 & 5.61 \\
\hline CGF07033 & 8.11 & 246.65 & CGF07060-3 & 7.23 & 33.23 & FAEM 006 & 8.50 & 5.51 \\
\hline CGF07060-2 & 7.42 & 243.96 & CGF07033 & 6.49 & 32.79 & CGF07033-1 & 6.88 & 5.40 \\
\hline CGF07041 & 6.82 & 241.59 & BRISA SUL & 5.81 & 32.38 & CGF07041 & 5.66 & 5.32 \\
\hline BRISA SUL & 6.22 & 239.25 & CGF07023-1 & 5.19 & 32.01 & CGF03006 & 4.57 & 5.24 \\
\hline $\begin{array}{l}\text { CGF07-027- } \\
1\end{array}$ & 5.68 & 237.13 & $\begin{array}{l}\text { CGF07-027- } \\
1\end{array}$ & 4.58 & 31.64 & CGF07033 & 3.36 & 5.16 \\
\hline FAEM 006 & 5.05 & 234.65 & FAEM 006 & 3.91 & 31.24 & CGF07060-3 & 2.12 & 5.07 \\
\hline $\begin{array}{l}\text { CHIARA } \\
\text { SUL }\end{array}$ & 2.35 & 224.06 & $\begin{array}{l}\text { BARBARA } \\
\text { SUL }\end{array}$ & 1.80 & 29.97 & $\begin{array}{l}\text { CGF07-027- } \\
1\end{array}$ & 0.97 & 4.99 \\
\hline $\begin{array}{l}\text { BARBARA } \\
\text { SUL }\end{array}$ & 0.00 & 214.88 & $\begin{array}{l}\text { CHIARA } \\
\text { SUL }\end{array}$ & 0.00 & 28.89 & CGF07060-2 & 0 & 4.93 \\
\hline TOTAL & 100.00 & & & 100.00 & & TOTAL & 100.00 & \\
\hline
\end{tabular}


Table 3. Ranking of white oats genotypes through best linear unbiased predictor (BLUP), gain with selection (\%) and new predicted means for the traits phosphorus content $(\mathrm{P})$; potassium content $(\mathrm{K})$; calcium content $(\mathrm{Ca})$; magnesium content $(\mathrm{Mg})$; manganese content $(\mathrm{Mn})$ and zinc content $(\mathrm{Zn})$.

\begin{tabular}{|c|c|c|c|c|c|c|c|c|}
\hline \multicolumn{3}{|c|}{$P$} & \multicolumn{3}{|c|}{$\mathrm{K}$} & \multicolumn{3}{|c|}{$\mathrm{Ca}$} \\
\hline Lineage & $\begin{array}{l}\text { Gain } \\
(\%)\end{array}$ & $\begin{array}{c}\text { New mean }(\mathrm{g} \\
\left.\mathrm{Kg}^{-1}\right)\end{array}$ & Lineage & $\begin{array}{l}\text { Gain } \\
(\%)\end{array}$ & $\begin{array}{c}\text { New mean }(\mathrm{g} \\
\left.\mathrm{Kg}^{-1}\right)\end{array}$ & Lineage & $\begin{array}{l}\text { Gain } \\
(\%)\end{array}$ & $\begin{array}{c}\text { New mean }(\mathrm{g} \\
\left.\mathrm{Kg}^{-1}\right)\end{array}$ \\
\hline $\begin{array}{l}\text { CGF07-027-1 } \\
\end{array}$ & 18.60 & 6.51 & \begin{tabular}{l|l} 
CGF07-027-1 & \\
\end{tabular} & 13.22 & 44.07 & $\begin{array}{l}\text { CGF07060-3 } \\
\end{array}$ & 16.90 & 5.39 \\
\hline CGF03006 & 14.73 & 6.25 & CGF03006 & 12.77 & 44.00 & CGF0705-7 & 15.60 & 5.33 \\
\hline CGF07041 & 12.55 & 6.10 & CGF07041 & 12.41 & 43.94 & CGF07060-2 & 13.41 & 5.21 \\
\hline CGF0705-7 & 10.77 & 5.98 & CGF07023-1 & 11.28 & 43.76 & CGF07041 & 11.91 & 5.14 \\
\hline CGF07023-1 & 9.62 & 5.90 & CGF07060-2 & 10.10 & 43.57 & CGF07033 & 10.02 & 5.04 \\
\hline CGF07033 & 8.47 & 5.82 & CGF07060-3 & 9.03 & 43.40 & CGF07033 & 8.09 & 4.94 \\
\hline BRISA SUL & 7.26 & 5.74 & CGF07033 & 7.95 & 43.22 & BRISA SUL & 6.63 & 4.87 \\
\hline CGF07060-2 & 5.94 & 5.65 & CGF0705-7 & 6.71 & 43.03 & FAEM 006 & 5.46 & 4.81 \\
\hline CGF07033-1 & 4.91 & 5.58 & BRISA SUL & 5.65 & 42.86 & $\begin{array}{c}\text { BARBARA } \\
\text { SUL }\end{array}$ & 4.49 & 4.76 \\
\hline CGF07060-3 & 3.59 & 5.49 & CGF07033-1 & 4.73 & 42.71 & CGF07-027-1 & 3.71 & 4.72 \\
\hline FAEM 006 & 2.42 & 5.41 & FAEM 006 & 3.88 & 42.57 & CGF03006 & 2.43 & 4.65 \\
\hline $\begin{array}{c}\text { BARBARA } \\
\text { SUL }\end{array}$ & 1.16 & 5.32 & $\begin{array}{c}\text { BARBARA } \\
\text { SUL }\end{array}$ & 2.26 & 42.31 & CGF07033-1 & 1.35 & 4.60 \\
\hline \multirow[t]{3}{*}{$\begin{array}{c}\text { CHIARA } \\
\text { SUL } \\
\end{array}$} & 0.00 & 5.25 & $\begin{array}{c}\text { CHIARA } \\
\text { SUL }\end{array}$ & 0.00 & 41.95 & CGF07023-1 & 0.00 & 4.53 \\
\hline & \multirow{2}{*}{\multicolumn{2}{|c|}{$\frac{100.00}{\mathrm{Mg}}$}} & \multirow{2}{*}{\multicolumn{3}{|c|}{$\frac{100.00}{\mathrm{Mn}}$}} & \multirow{2}{*}{\multicolumn{3}{|c|}{$\mathrm{Zn}$}} \\
\hline & & $\mathrm{Mg}$ & \multicolumn{2}{|r|}{$\mathrm{Mn}$} & & & & \\
\hline Lineage & $\begin{array}{l}\text { Gain } \\
(\%)\end{array}$ & $\begin{array}{c}\text { New mean }(\mathrm{g} \\
\left.\mathrm{Kg}^{-1}\right)\end{array}$ & Lineage & $\begin{array}{l}\text { Gain } \\
(\%)\end{array}$ & $\begin{array}{c}\text { New mean (mg } \\
\left.\mathrm{Kg}^{-1}\right)\end{array}$ & Lineage & $\begin{array}{l}\text { Gain } \\
(\%)\end{array}$ & $\begin{array}{l}\text { New mean } \\
\left(\mathrm{mg} \mathrm{Kg}^{-1}\right)\end{array}$ \\
\hline CGF0705-7 & 18.03 & 3.41 & FAEM 006 & 18.03 & 134.13 & CGF30006 & 15.37 & 33.39 \\
\hline CGF07041 & 15.94 & 3.35 & CGF07023-1 & 16.19 & 130.60 & BRISA SUL & 14.07 & 33.08 \\
\hline CGF07033 & 12.96 & 3.26 & CGF07-027-1 & 12.84 & 124.23 & CGF07041 & 12.82 & 32.79 \\
\hline BRISA SUL & 11.19 & 3.21 & $\begin{array}{l}\text { BARBARA } \\
\text { SUL }\end{array}$ & 11.17 & 121.04 & CGF07033 & 11.81 & 32.56 \\
\hline CGF07-027-1 & 9.99 & 3.17 & CGF07060-2 & 9.58 & 118.01 & CGF07023-1 & 10.99 & 32.37 \\
\hline CGF03006 & 8.71 & 3.13 & $\begin{array}{l}\text { CHIARA } \\
\text { SUL }\end{array}$ & 8.44 & 115.82 & CGF0705-7 & 9.37 & 31.99 \\
\hline CGF07060-2 & 7.01 & 3.08 & CGF07041 & 7.39 & 113.82 & CGF07-027-1 & 7.47 & 31.55 \\
\hline CGF07060-3 & 5.51 & 3.04 & CGF07060-3 & 5.97 & 111.12 & $\begin{array}{l}\text { BARBARA } \\
\text { SUL }\end{array}$ & 5.98 & 31.20 \\
\hline FAEM 006 & 4.30 & 3.00 & BRISA SUL & 4.37 & 108.05 & FAEM 006 & 4.81 & 30.93 \\
\hline CGF07023-1 & 3.19 & 2.97 & CGF03006 & 3.05 & 105.54 & CGF07060-3 & 3.68 & 30.67 \\
\hline $\begin{array}{l}\text { BARBARA } \\
\text { SUL }\end{array}$ & 2.06 & 2.94 & CGF07033-1 & 1.96 & 103.46 & CGF07060-2 & 2.42 & 30.37 \\
\hline CGF07033-1 & 1.10 & 2.91 & CGF07033 & 1.02 & 101.67 & CGF07033-1 & 1.22 & 30.09 \\
\hline $\begin{array}{c}\text { CHIARA } \\
\text { SUL }\end{array}$ & 0.00 & 2.88 & CGF0705-7 & 0.00 & 99.73 & $\begin{array}{c}\text { CHIARA } \\
\text { SUL }\end{array}$ & 0.00 & 29.81 \\
\hline TOTAL & 100.00 & & & 100.00 & & & & \\
\hline
\end{tabular}

\section{Multi-trait selection through factor analysis}

To attend this assumption, five final factors were considered (Table 4), which gathered an estimate of $85.42 \%$ of the total variation verified in the measured traits. Only traits that presented factorial loads equal to or greater than 0.7 were considered for definition of multi-traits due to the presence of correlation between them (Johnson and Wichern, 1992). Considering the factor I, factorial loads greater than 0.70 allowed to group the traits magnesium content $(0.806)$ and Zinc $(0.880)$, which formed the multi-trait I. Factor 2 reunited the traits dry mass $(0.893)$ and fresh mass $(0.835)$, forming the multi-trait II. Regarding the factor 3 , it was possible to verify the affinity between nitrogen (0.832) and calcium (0.908) contents, which were considered as multi-trait III. Factor 4 enabled to group crude protein percentage $(0.825)$ and potassium content $(-0.792)$ which represented the multi-trait IV. In contrast, factor 5 did not allow associations between traits, so the number of tillers per linear meter (0.892) represented the multi-trait V. This condition was met by all analyzed traits (Table 4 ). 


\begin{tabular}{|c|c|c|c|c|c|c|c|}
\hline \multirow{2}{*}{$\lambda^{(1)}$} & \multirow{2}{*}{ Trait } & \multicolumn{5}{|c|}{ Factorial loads after rotation } & \multirow{2}{*}{$\Phi^{(2)}$} \\
\hline & & Factor 1 & Factor 2 & Factor 3 & Factor 4 & Factor 5 & \\
\hline 5.081 & $\mathrm{PH}$ & 0.157 & 0.679 & 0.058 & -0.501 & -0.242 & 0.801 \\
\hline 2.787 & NT & 0.269 & 0.179 & -0.465 & 0.932 & 0.892 & 0.911 \\
\hline 1.621 & DM & 0.002 & 0.893 & 0.133 & -0.036 & 0.264 & 0.886 \\
\hline 1.399 & FM & -0.250 & 0.835 & -0.550 & -0.266 & 0.381 & 0.917 \\
\hline 1.070 & LA & 0.383 & 0.167 & 0.230 & -0.047 & 0.648 & 0.651 \\
\hline 0.721 & $\mathrm{CP}$ & 0.865 & -0.213 & -0.391 & 0.825 & -0.091 & 0.895 \\
\hline 0.515 & $\mathrm{~N}$ & -0.170 & 0.214 & 0.832 & 0.113 & 0.078 & 0.773 \\
\hline 0.341 & $\mathrm{Ca}$ & 0.147 & 0.002 & 0.908 & -0.096 & 0.170 & 0.885 \\
\hline 0.231 & $\mathrm{Fe}$ & 0.177 & -0.096 & -0.292 & -0.444 & 0.678 & 0.753 \\
\hline 0.155 & $\mathrm{P}$ & 0.600 & 0.121 & -0.181 & -0.523 & 0.458 & 0.892 \\
\hline 0.062 & $\mathrm{Mg}$ & 0.806 & 0.165 & 0.460 & -0.126 & 0.230 & 0.959 \\
\hline 0.006 & $\mathrm{Mn}$ & -0.365 & -0.744 & -0.272 & -0.120 & 0.170 & 0.804 \\
\hline-0.001 & $\mathrm{~K}$ & 0.392 & 0.078 & -0.107 & -0.792 & 0.389 & 0.951 \\
\hline-0.000 & $\mathrm{Zn}$ & 0.880 & 0.063 & -0.214 & -0.050 & 0.217 & 0.873 \\
\hline
\end{tabular}

In this way, five multi-traits were stablished for selection: multi-trait $\mathrm{I}(\mathrm{MG}+\mathrm{Zn})$, multi-trait II (DM + FM), multi-trait III $(\mathrm{N}+\mathrm{Ca})$, multi-trait IV $(\mathrm{CP}+\mathrm{K})$ and multi-trait V (NT). The multi-traits were expressed graphically in order to select the genotypes, where quadrant I expresses the possibility of selecting genotypes for both multi-traits, the quadrants II and IV correspond to the selection for a specific multi-trait, while quadrant III reunites the genotypes that are not suitable for multi-trait selection.

Graph A (Figure 1) evidences that genotypes BRISASUL, CGF03006, CGF07033, CGF07033-1, CGF07041, CGF0705-7, CGF07060-2 and CGF07060-3 may be selected for the multi-traits $\mathrm{FM}+\mathrm{DM}$ and $\mathrm{MG}+\mathrm{Zn}$, simultaneously. However, the genotypes CHIARASUL, FAEM006, BARBARASUL, CGF07023-1 and CGF07-027-1 may be selected exclusively though the multi-trait MG $+\mathrm{Zn}$. In graph B (Figure 1), the genotypes BRISASUL, CGF03006, CGF07033, CGF07033-1, CGF07041, CGF0705-7, CGF07060-2 and CGF07060-3 may be considered for simultaneous selection through $\mathrm{N}+\mathrm{Ca}$ and FM + DM. On the other hand, CHIARASUL, FAEM006, BARBARASUL, CGF07023-1 and CGF07-027-1 should be selected exclusively to increase the multi-trait N + Ca. Graph C (Figure 1) shows that all genotypes may be selected when the objective is to increase the multi-trait N+Ca. Graph D (Figure 1) evidenced that all genotypes have potential for increasing the NT multi-trait.

From the results verified in this study, the largest estimates of genetic variance were observed for number of tillers per linear meter, green and dry mass of forage, and leaf area, which demonstrates great influence of genetic effects on their phenotypic variation. Also, selection performed through the (BLUP) pointed the genotype CGF0705-7 as promising for morphological aspects, however it does not present the best magnitudes of traits regarding bromatological quality. The BLUP methodology demonstrated great efficiency in the selection of genotypes for specific and univariate traits, however, multivariate selection is expressed as a viable alternative in the identification of which genotypes should be selected. Furthermore, the analysis of factors allowed to define five multi-traits (MG+Zn, DM+FM, $\mathrm{N}+\mathrm{Ca}, \mathrm{CP}+\mathrm{K}$ and NT) that could be used for multivariate selection. The highest efficiency of selection was obtained through the multi-trait $\mathrm{N}+\mathrm{Ca}$, which allowed to select the largest number of genotypes. The combined use of these methods allows to increase the efficiency 
of univariate and multivariate selection, with potential to be used in the genetic breeding of white oats with forage purpose.
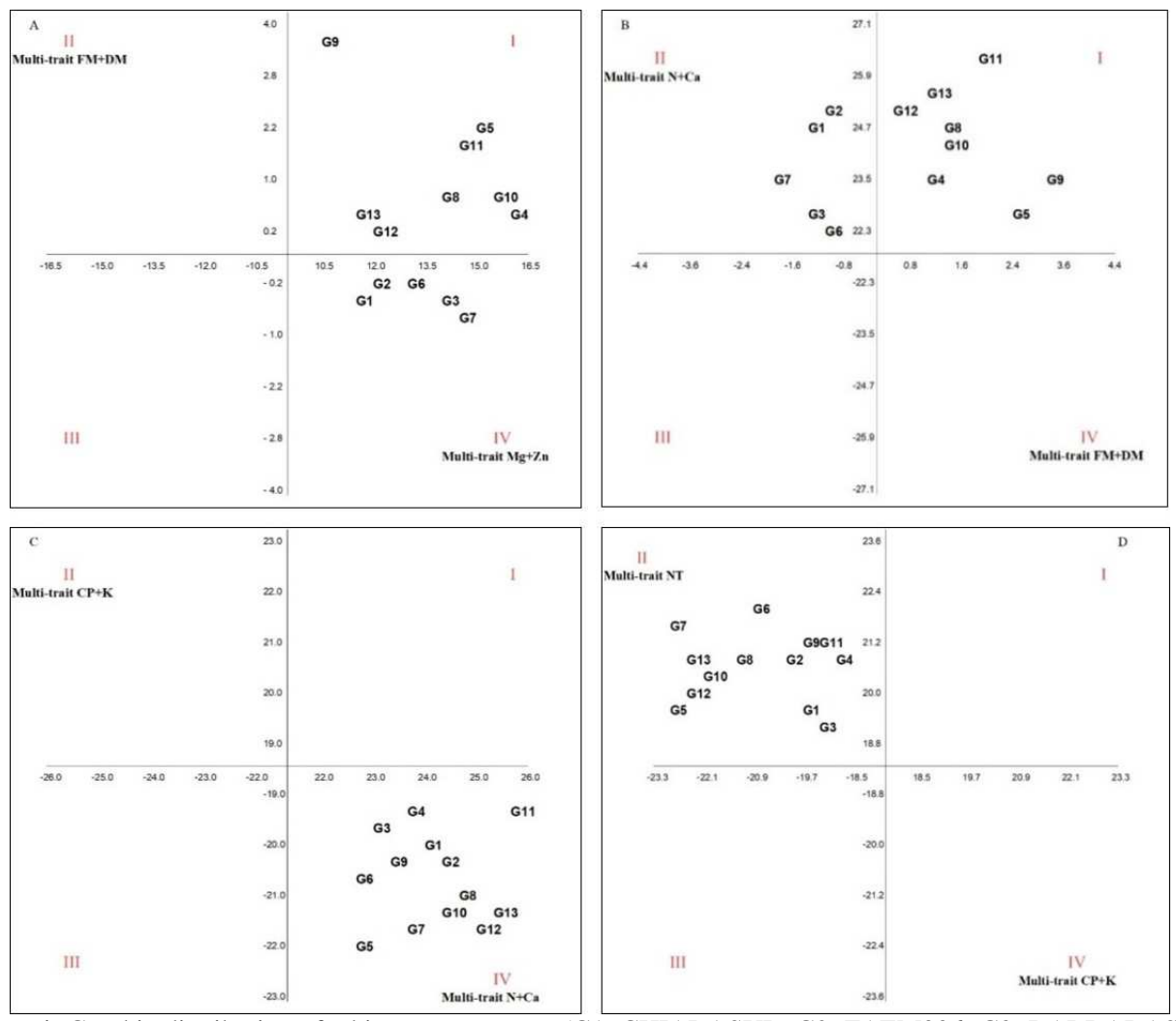

Figure 1. Graphic distribution of white oat genotypes (G1: CHIARASUL; G2: FAEM006; G3: BARBARASUL; G4: BRISASUL; G5: CGF03006; G6: CGF07023-1; G7: CGF07-027-1; G8: CGF07033; G9: CGF07033-1; G10: CGF07041; G11 CGF0705-7; G12: CGF07060-2; G13: CGF07060-3) according to the multi-trait scores defined through factor analysis.

\section{CONCLUSIONS}

The white oat genotypes expressed high genetic variability and possibility of selection for leaf area, fresh forage mass, dry forage mass, number of tillers and calcium content. Simultaneously the magnesium content with multiple traits + zinc content, dry matter + fresh mass, nitrogen content + calcium content, crude protein + potassium content and number of tillers showed potential for selection of genotypes for genetic improvement.

\section{ACKNOWLEDGMENTS}

We thank the Centro Universitário de Mineiros for the support and partnerships of the Regional University of the Northwest of the State of Rio Grande do Sul and the Federal University of Pelotas. 


\section{CONFLICTS OF INTEREST}

The authors declare no conflict of interest.

\section{REFERENCES}

Berry PM and Berry ST (2015). Understanding the genetic control of lodging-associated plant characters in winter wheat (Triticum aestivum L.). Euphytica. 205(3): 671-689. https://link.springer.com/article/10.1007/s10681-015-1387-2.

Bibi A, Shahzad A, Sadaqat HA, Tahir MHN, et al. (2012) Genetic characterization and inheritance studies of oats (Avena sativa L.) for green fodder yield. Int. J. Biol. Pharm. Allied Sci. 1: 450-460.

Borges V, Ferreira PV, Soares L, Santos GM, et al. (2010). Seleção de clones de batata-doce pelo procedimento REML/BLUP. Acta Sci. Agron. 32(4): 643-649. https://doi.org/10.4025/actasciagron.v32i4.4837.

Carvalho IRC, Nardino M, Demari GH, Bahry CA, et al. (2016). Bi-segmented regression, factor analysis and AMMI applied to the analysis of adaptability and stability of soybean. Aust. J. Crop Sci. 10(10): 1410-1416.

Cruz CD (2016). Genes Software - extended and integrated with the R, Matlab and Selegen. Acta Sci. Agron. 38(4): 547-552. https://doi.org/10.4025/actasciagron.v38i4.32629

David DB, Nörnberg JL, Azevedo EB, Brüning G, et al. (2010) Nutritional value of black and white oat cultivars ensiled in two phenological stages. Rev. Bras. Zootec. 39(7): 1409-1417. https://doi.org/10.1590/S151635982010000700003 .

Deiss L, Moraes A, Pelissari A, Skora Neto, et al. (2014). Oat tillering and tiller traits under different nitrogen levels in an eucalyptus agroforestry system in Subtropical Brazil. Cienc. Rural. 44(1): 25-30. https://doi.org/10.1590/S010384782014000100012

Dubey N, Avinashe HA, Jaiwar S and Chichkhede L (2014). Estimates of genetic variability, heritability and genetic advance of oat (Avena sativa L.) genotypes for green fodder yield. Electron. J. Plant Breed. 5: 881-883.

Gill KS, Omokanye AT, Pettyjohn JP and Elsen M (2013). Agronomic Performance and Beef Cattle Nutrition Suitability of Forage Oat Varieties Grown in the Peace Region of Alberta, Canada. J. Agri. Sci. 5(7): 7-12. http://dx.doi.org/10.5539/jas.v5n7p128.

Huuskonen A (2009). The effect of cereal type (barley versus oats) and rapeseed meal supplementation on the performance of growing and finishing dairy bulls offered grass silage-based diets. Livest. Sci. 122(1): 53-62. https://doi.org/10.1016/j.livsci.2008.07.023.

Irfan M, Ansar M, Sher A, Wasaya A, et al. (2016). Improving forage yield and morphology of oat varieties through various row spacing and nitrogen application. J. Anim. Plant Sci. 26(6): 1718-1724. http://www.thejaps.org.pk/docs/v-26-06/24.pdf.

Johnson RA and Wichern DW (1992). Applied multivariate statistical analysis. Prentice Hall, New Jersey.

Joubert AJ and Myburgh WJA (2014). Comparison of Three Dry Matter Forage Production Methods Used in South Africa. Int. J. Ecol. 2014: 314939. https://doi.org/10.1155/2014/314939.

Kim KS, Tinker NA and Newell MA (2014). Improvement of oat as a winter forage crop in the Southern United States. Crop Sci. 54: 1336-1346. https://doi:10.2135/cropsci2013.07.0505.

Kumar BS, Singh RV, Gupta KG and Ravinder J (2017). Effect of nitrogen levels and cutting management on green forage yield of fodder oat (Avena sativa L.). J. Pharmacogn Phytochem. v. 6, n. 5, p. 635-637, 2017.

Liu K and Mahmood K (2015). Nutrient Composition and Protein Extractability of Oat Forage Harvested at Different Maturity Stages as Compared to Grain. J. Agricul. Sci. 7(12): 45-49. http://dx.doi.org/10.5539/jas.v7n12p50.

Lourenço VM, Rodrigues PC, Pires AM and Piepho HP (2017). A robust DF-REML framework for variance components estimation in genetic studies. Bioinformatics. 33: 3584-3594. https://doi.org/10.1093/bioinformatics/btx457.

Murakami DM and Cruz CD (2004) Proposal of methodologies for environment stratification and analysis of genotype

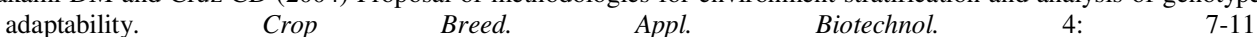
https://pdfs.semanticscholar.org/4a82/3de81eae590fd47aea1b1166cb07db878725.pdf.

Nava IC, Duarte ITL, Pacheco MT and Federizzi LC (2010). Genetic control of agronomic traits in an oat population of recombinant lines. Crop Breed. Appl. Biotechnol. 10: 305-311. https://doi.org/10.1590/S198470332010000400004

Nuvunga JJ, Oliveira LA, Pamplona AKA, Silva CP, et al. (2015). Factor analysis using mixed models of multienvironment trials with different levels of unbalancing. Genet. Mol. Res. 14: 14262-14278. http://dx.doi.org/10.4238/2015.November.13.10.

Pimentel AJB, Guimarães JFR, Souza MA, Resende MDV, et al. (2014). Estimação de parâmetros genéticos e predição de valor genético aditivo de trigo utilizando modelos mistos. Pesqui. Agropecu. Bras. 49: 882-890.

Resende MDV (2002). Genética biométrica e estatística no melhoramento de plantas perenes. Embrapa Informação Tecnológica. 
Resende MDV (2016). Software Selegen-REML/BLUP: a useful tool for plant breeding. Crop Breed. Appl. Biotechnol. 16: 4-10. https://doi.org/10.1590/1984-70332016v16n4a49.

Resende MDV and Duarte JB (2007) Precisão e controle de qualidade em experimentos de avaliação de cultivares. Pesq. Agropec. Trop. 37: 182-194. http://www.alice.cnptia.embrapa.br/alice/handle/doc/313450.

Rocha JRASC, Machado JC and Carneiro PCS (2017). Multitrait index based on factor analysis and ideotype-design: proposal and application on elephant grass breeding for bioenergy. GCB Bioenergy. 10: 52-60. https://doi.org/10.1111/gcbb.12443.

Roy C, Verma JS and Yadav A (2013). Genetic analysis for forage and grain yield and their quality parameters in oat (Avena sativa L.). Pant. J. Res. 11: 267-293. https://www.cabdirect.org/cabdirect/abstract/20133380647.

Saleem M, Zamir MSI, Haq I, Irshad MZ, et al. (2015). Yield and Quality of Forage Oat (Avena sativa L.) Cultivars as Affected by Seed Inoculation with Nitrogenous Strains. Am. J. Plant Sci. 6: 3251-3259. https://www.scirp.org/html/25-2602214_62161.htm.

SAS Institute (2018). Getting started with SAS learning edition (Cary: SAS Publishing).

Shapiro SS and Wilk MB (1965). An Analysis of Variance Test for Normality (Complete Samples). Biometrika. 52: 591611. https://DOI: $10.2307 / 2333709$.

Soetan KO, Olaiya CO and Oyewole EO (2010). The importance of mineral elements for humans, domestic animals and plants: A review. Afr. J. Food Sci. 4: 200-222.

Suttie JM and Reynolds SG (2004). Fodder oats: a world overview. Food \& Agriculture Org., Rome

Ticona-Benavente CA and Silva Filho DF (2015). Comparison of BLUE and BLUP/REML in the selection of clones and families of potato (Solanum tuberosum). Genet. Mol. Res. 14: 18421-18430. http://dx.doi.org/10.4238/2015.December.23.30.

Tremblay GF, Bélanger G, Mcrae KB and Michaud R (2001). Leaf and stem dry matter digestibility and ruminal undegradable proteins of alfalfa cultivars. Can. J. Plant Sci. 82: 83-393. https://doi.org/10.4141/P01-122.

Tumino G, Voorrips RE, Morcia C, Ghizzoni R, et al. (2017). Genome-wide association analysis for lodging tolerance and plant height in a diverse European hexaploid oat collection. Euphytica. 213: 163-170. https://link.springer.com/article/10.1007/s10681-017-1939-8.

Vencovsky R. Herança quantitativa. In: Paterniani E (1978). Melhoramento e produção de milho no Brasil. Fundação Cargill, Piracicaba.

Yatoo MI, Saxena A, Deepa PM, Habeab BP, et al. (2013). Role of trace elements in animals: a review. Vet. World. 6: 17. https://doi: 10.14202/vetworld.2013.963-967.

Zadoks JC, Chang TT and Konzac CF (1974). A decimal code for the growth stages of cereals. Weed Res. 14: 415-421. https://doi.org/10.1111/j.1365-3180.1974.tb01084.x 